\title{
ADVANCED SCIENCE AND TECHNOLOGY OF SINTERING
}




\section{ADVANCED SCIENCE AND TECHNOLOGY OF SINTERING}

Edited by

\section{Biljana D. Stojanović}

Center for Multidisciplinary Studies University of Belgrade

Belgrade, Yugoslavia

\section{Valery V. Skorokhod}

Institute for Problems of Materials Science

of the Ukrainian Academy of Sciences

Kiev, Ukraine

and

\section{Maria Vesna Nikolić}

Joint Laboratory for Advanced Materials of the Serbian Academy of Sciences and Arts

Belgrade, Yugoslavia

Springer Science+Business Media, LLC 
Advanced science and technology of sintering/edited by Biljana D. Stojanovic, Valery

V. Skorokhod and Maria Vesna Nikolic.

p. $\mathrm{cm}$.

Includes bibliographical references and index.

1. Sintering. I. Stojanovic, Biljana D. II. Skorokhod, V. V. (Valerii Vladimirovich) III. Nikolic, Maria Vesna

TN697.17 A38 1999

$671.3^{\prime} 73-\mathrm{dc} 21$

99-047696

\section{ISBN 978-1-4613-4661-6 ISBN 978-1-4419-8666-5 (eBook)}

DOI 10.1007/978-1-4419-8666-5

Proceedings of the Ninth World Round Table Conference on Sintering, held September 1-4, 1998, in Belgrade, Yugoslavia

(C)1999 Springer Science+Business Media New York

Originally published by Kluwer Academic/Plenum Publishers, New York 1999

Softcover reprint of the hardcover 1st edition 1999

$\begin{array}{llllllllll}10 & 9 & 8 & 7 & 6 & 5 & 4 & 3 & 2 & 1\end{array}$

A C.I.P. record for this book is available from the Library of Congress

All rights reserved

No part of this book may be reproduced, stored in a retrieval system, or transmitted in any form or by any means, electronic, mechanical, photocopying, microfilming, recording, or otherwise, without written permission from the Publisher 


\section{PREFACE}

This volume entitled Advanced Science and Technology of Sintering, contains the edited Proceedings of the Ninth World Round Table Conference on Sintering (IX WRTCS), held in Belgrade, Yugoslavia, September 1-4 1998. The gathering was one in a series of World Round Table Conferences on Sintering organised every four years by the Serbian Academy of Sciences and Arts (SASA) and the International Institute for the Science of Sintering (IISS).

The World Round Table Conferences on Sintering have been traditionally held in Yugoslavia. The first meeting was organised in Herceg Novi in 1969 and since then they have regularly gathered the scientific elite in the science of sintering. It is not by chance that, at these conferences, G. C. Kuczynski, G. V. Samsonov, R. Coble, Ya. E. Geguzin and other great names in this branch of science presented their latest results making great qualitative leaps in the its development.

Belgrade hosted this conference for the first time. It was chosen as a reminder that 30 years ago it was the place where the International Team for Sintering was formed, further growing into the International Institute for the Science of Sintering.

The IX WRTCS lasted four days. It included 156 participants from 17 countries who presented the results of their theoretical and experimental research in 130 papers in the form of plenary lectures, oral presentations and poster sections. The presentation of each contributed paper proved to be a good opportunity for free and informal discussion. This enabled a broad analysis of the current state of the science of sintering and gave perspectives for the further development of the theory and technology of sintering. Fundamental scientific problems were addressed as well as the technological state-of-the-art in sintering and sintering materials, including sintered materials of advanced technology used in a variety of research and industrial applications. In the opinion of the editor, this conference was characterized by the high level and broad scope of reports on the advanced science and technology of sintering.

This volume includes 92 papers selected by the editors and organised into seven sections which comprise this book, as follows: (1) Fundamentals (2) Nanostructured Powders (3) Mechanical Activation (4) Sintering of Oxide Systems (5) Electronic Ceramics (6) Non-Oxide Materials (7) Sintering of Metal Powders.

We would like to acknowledge the useful advice and considerable assistance of the General Secretary of the International Institute for the Science of Sintering and President of the Organization Committee, Academician Momčilo M. Ristić and also the International Program and Organization Committee, Session Chairmen, as well as the creative efforts of the distinguished contributing authors representing 
many of the world centres for sintering research. We extend our personal thanks for their cooperative attitudes, timely responses, and many helpful suggestions.

We wish to express our gratitude to the patron of the International Institute for the Science of Sintering, the Serbian Academy of Sciences and Arts, as well as the Centre for Multidisciplinary Studies at the University of Belgrade, and the Institute of Technical Sciences of SASA in Belgrade for their support in the organization of the conference. We also note with gratitude the financial support for the conference organization provided by the principal sponsor, the Ministry for Science and Technology of the Republic of Serbia, Potisje Kanjiža, Kanjiža, the Cement factory, Kosjerić, the Institute of Nuclear Sciences "Vinča”, the Institute of Chemistry, Technology and Metallurgy, Belgrade, the Institute for Technology of Nuclear and Other Mineral Raw Materials, Belgrade, the Technical Faculty, Čačak, the Electronic Faculty, Niš, the Faculty for Technology and Metallurgy, Belgrade, the Scientific Research Centre, Užice, IRITEL, Belgrade, ICN Yugoslavia, Petrohemija, Pančevo and RTB Bor, Bor.

We wish to acknowledge a small group of individuals who worked with great dedication behind the scenes: Nataša Nikolić, Bojan Marinković, Mirjana Kosanović and Ljiljana Milošević for their assistance in preparing materials before, during and after the conference; Aleksandar Kosanović and Dragan Tasić for providing technical service; Voja Glavonjić and his staff from the Printing Office of the Serbian Academy of Sciences and Arts for preparing all materials for the conference; Dr Stamenka Radić for translation services, Nikola Čajkanović, Ljiljana Nedeljković, Ivana Sevicki and Vukica Đapa for simultaneous translation during the conference, and Emina Ljutić for efficient typing of the conference materials.

It is also our pleasure to thank Goran Branković and Aleksandar Tucić for their help in the preparation of the proceedings, as well as Tatjana Srećković, Vesna Minić, Lidija Mančić and Zorica Marinković for performing various tasks and preparing materials for the conference.

Lastly, we would like to acknowledge with affection the patience, tolerance, and moral support we have been given by our colleagues and families through those extended periods of time when we had to pay attention to organizing the conference and editing these proceedings.

Biljana D. Stojanović Valery V. Skorokhod Maria Vesna Nikolić 


\title{
INVESTIGATION OF THE MICROSTRUCTURE AND DISTRIBUTION OF SOLUTE DURING SOLIDIFICATION OF Al-Cu ALLOY
}

\author{
Vesna J. Radojević ${ }^{1}$, Andreja V. Valčić ${ }^{1}$, Slobodanka N. Nikolić ${ }^{2}$ and \\ Aleksandra D. Milutinović-Nikolić \\ ${ }^{1}$ Faculty of Technology and Metallurgy \\ 11000 Belgrade, Yugoslavia \\ ${ }^{2}$ Institute of Chemistry, Technology and Metallurgy \\ 11000 Belgrade, Yugoslavia
}

\section{INTRODUCTION}

Phenomenon of solidification process plays an important role in various areas like: crystal growth, casting processes, liquid phase sintering etc. Results presented in this paper contribute to investigation of the influence of solidification rate (R) on the interface shape and the solute segregation.

When a binary alloy is solidified in a temperature gradient the solid-liquid interface tends to a cellular morphology when the solidification parameters (solidification rate - $\mathrm{R}$, temperature gradient $-\mathrm{G}$, and solute concentration $-\mathrm{C}_{0}$ ) are controlled within certain limits. It was observed that the planar interface became unstable above a critical rate given approximately by ${ }^{1}$ :

$$
\frac{G_{L}}{R_{P C}}=-\frac{m_{L} C_{0}\left(1-k_{0}\right)}{k_{0} D_{L}}
$$

Where $G_{L}$ is the temperature gradient in the liquid phase, $R_{P C}$ the critical solidification rate for a planar-to-cellular transition, $\mathrm{C}_{0}$ the initial solute concentration, $\mathrm{m}_{\mathrm{L}}$ the liquid line slope in the equilibrium diagram, $\mathrm{k}_{0}$ the equilibrium coefficient of distribution, $\mathrm{D}_{\mathrm{L}}$ the coefficient of diffusion in the liquid phase.

As the solidification rate was increased above $R_{P C}$ the interface morphology became oscillatory unstable, then cellular and at large velocities, dendritic. Near the critical rate, $\mathrm{R}_{\mathrm{PC}}$, the interface exhibited an irregular morphology.

In the case of normal solidification (Vertical Bridgman method) the whole charge is molten and it solidifies from one end to another. The distribution of solute concentration in the solid phase can be described by equation $(2)^{1,2}$ :

$$
\mathrm{C}_{\mathrm{S}}=\mathrm{C}_{0} \mathrm{k}_{0}(1-\mathrm{g})^{\mathrm{k}_{0}-1}
$$


Where $\mathrm{C}_{\mathrm{S}}$ is the concentration of solute in the solid phase, $\mathrm{C}_{0}$ is the initial concentration of solutes in the liquid phase, $\mathrm{k}_{0}$ is the equilibrium distribution coefficient and $\mathrm{g}$ is the fraction of solidified material.

In the real systems the effective distribution coefficient is used instead of the equilibrium one, equation (3). The $\mathrm{k}_{\mathrm{e}}$ value varies between $\mathrm{k}_{0}$ (the equilibrium distribution coefficient) and 1 (when actually there is no segregation of the solute), depending on solidification rates.

$$
\mathrm{C}_{\mathrm{S}}=\mathrm{C}_{0} \mathrm{k}_{\mathrm{e}}(1-\mathrm{g})^{\mathrm{k}_{\mathrm{e}}-1}
$$

\section{EXPERIMENTAL}

The method of normal solidification in a Vertical Bridgman system was used ${ }^{3}$.

The experiments were carried out over a range of solidification rates from $1.45 \times 10^{-4}$ to $8.71 \times 10^{-3} \mathrm{~cm} / \mathrm{s}$, under a protective nitrogen atmosphere.

An $\mathrm{Al}-2.86 \% \mathrm{Cu}$ alloy was used in the experimental work. The solidified samples were longitudinal cut, polished, etched and then metallographic investigations of the microstructure were performed.

Optical emission spectrometry was used for chemical analysis of distribution of the solute concentration across the specimen.

\section{RESULTS AND DISCUSSION}

The assumption was made that the crystallization front moved through the sample at a rate equal to the descending rate of the ampoule.

Equation (1) was used to calculate $R_{P C}$. The values for $m_{L}, k_{0}, D_{L}$ and $G_{L}$, used in the calculation, are presented in Table 1 . Thus, $\mathrm{m}_{\mathrm{L}}$ was calculated from the Al-Cu equilibrium diagram, while the values for $\mathrm{k}_{0}^{4}$ and $\mathrm{D}_{\mathrm{L}}^{5-7}$ were taken from the literature. Temperature gradient in melt was calculated using mathematical model established according to experimental measurements of temperature gradient in the furnace. The calculated value for $\mathrm{R}_{\mathrm{PC}}$ was $7.48 \times 10^{-6} \mathrm{~cm} / \mathrm{s}$.

Table 1. Data used in the calculation of $\mathrm{R}_{\mathrm{PC}}$

\begin{tabular}{ll}
\hline $\mathrm{m}_{\mathrm{L}}\left({ }^{\circ} \mathrm{C} / \%\right)$ & -3.4 \\
$\mathrm{k}_{0}$ & 0.153 \\
$\mathrm{D}\left(\mathrm{cm}^{2} / \mathrm{s}\right)$ & $2.2 \times 10^{-5}$ \\
$\mathrm{G}\left({ }^{\circ} \mathrm{C} / \mathrm{cm}\right)$ & 18.3 \\
\hline
\end{tabular}

It was observed that the solidification rate at which the formation of cellular structures begins is greatly different from the calculated value for $\mathrm{R}_{\mathrm{PC}} 7$. The transformation occurs gradually through the stages from the planar interface to regular cells within certain range of solidification rates. The calculated value $\mathrm{R}_{\mathrm{PC}}$ is the rate when the planar interface became unstable. The cells are beginning to form at much higher rates. The existence of convection in real system is one of explanation for this deviation, whereas the theoretical model was developed with assumption that there is no convection. Therefore, the experiments were 
carried out over a range of solidification rates from $1.45 \times 10^{-4} \mathrm{~cm} / \mathrm{s}$ to $8.71 \times 10^{-3} \mathrm{~cm} / \mathrm{s}$, and the planar-to-cellular transition was expected about solidification rate $\mathrm{R}=7.5 \times 10^{-4} \mathrm{~cm} / \mathrm{s}$. The microstructures of samples grown on different rates are presented in Figures (1-5).

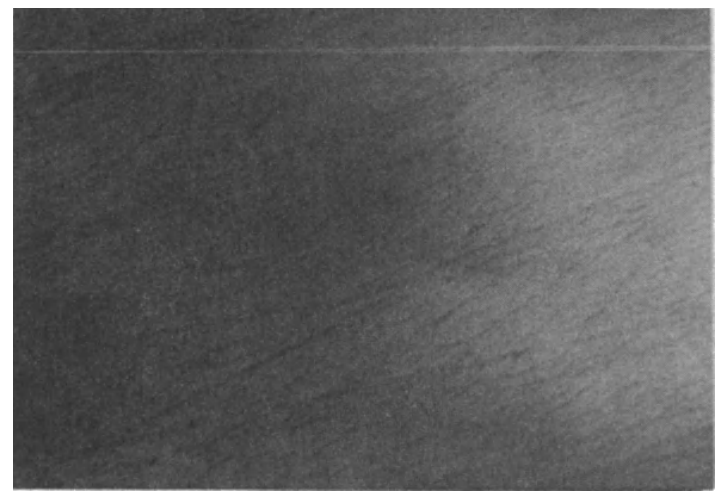

Figure 1. Microstructure of sample solidified with $\mathrm{R}=1.45 \times 10^{-4} \mathrm{~cm} / \mathrm{s}$, interface - planar (magnification $\times 24$ )

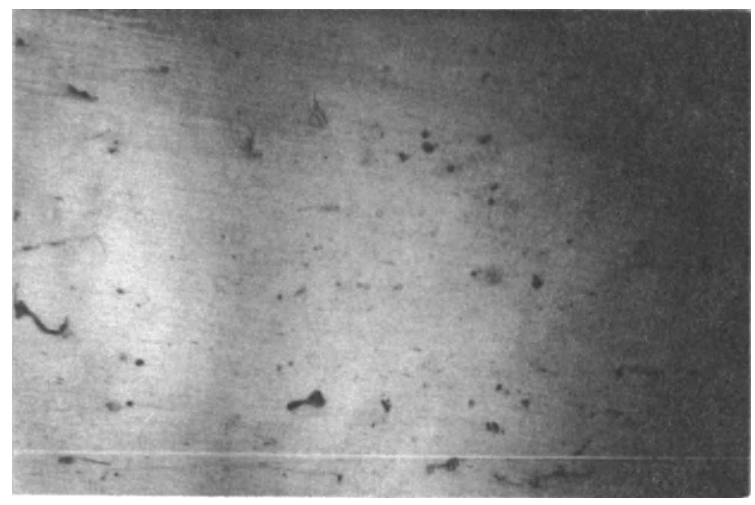

Figure 2. Microstructure of sample solidified with $\mathrm{R}=2.9 \times 10^{-4} \mathrm{~cm} / \mathrm{s}$, appearance of nodes (magnification $\times 24$ )

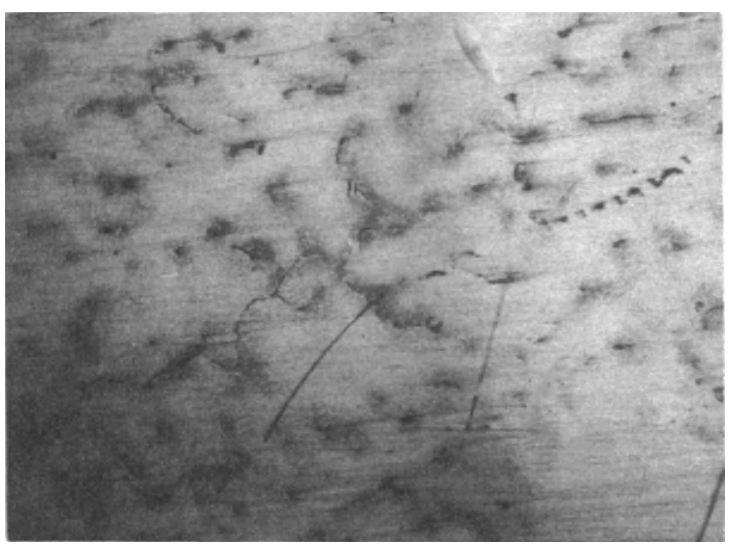

Figure 3. Microstructure of sample solidified with $\mathrm{R}=4.3 .5 \times 10^{-4} \mathrm{~cm} / \mathrm{s}$, elongated nodes (magnification $\times 24$ ) 


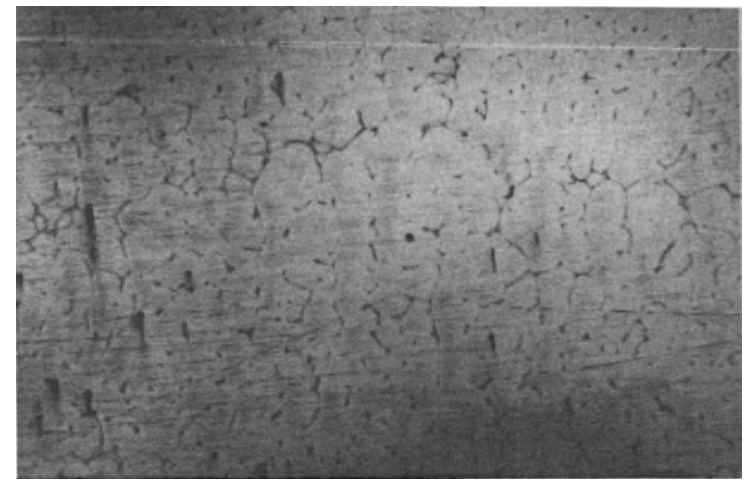

Figure 4. Microstructure of sample solidified with $R=8.71 \times 10^{-4} \mathrm{~cm} / \mathrm{s}$, beginning of the connection of the cells (magnification $\times 24$ )

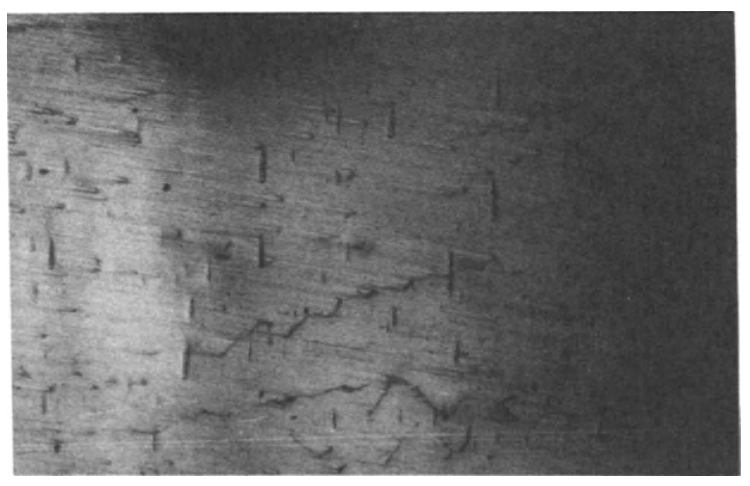

Figure 5. Microstructure of sample solidified with $R=8.71 \times 10^{-3} \mathrm{~cm} / \mathrm{s}$, irregular cells (magnification $\times 24$ )

The beginning of connection irregular cells is observed at rate $8.71 \times 10^{-4} \mathrm{~cm} / \mathrm{s}$. It is obvious that the range of experimental rates lies within unstable region of cell formation.

According to distribution of the solute across the sample, from the equation $(3)^{8}$ the effective distribution coefficient $\mathrm{k}_{\mathrm{e}}$ was calculated for each solidification rate (Table 2). For the maximal value of experimental solidification rate $\mathrm{k}_{\mathrm{e}}$ reached value 1 , when practically no distribution of the solute occurred.

Table 2. Effective distribution coefficient $\mathrm{k}_{\mathrm{e}}$ for each solidification rate

\begin{tabular}{ll}
\hline $\mathrm{R} \times 10^{3} \frac{\mathrm{cm}}{\mathrm{s}}$ & $\mathrm{k}_{\mathrm{e}}$ \\
\hline 8.71 & 1 \\
0.87 & 0.81 \\
0.43 & 0.86 \\
0.29 & 0.89 \\
\hline
\end{tabular}




\section{CONCLUSION}

In this study the influence of the solidification rate on the microstructure and solute distribution was investigated. Solidification of $\mathrm{Al}-2.86 \% \mathrm{Cu}$ alloy was performed using Vertical Bridgman method.

According quantitative criterion the critical rate for plane-to-cellular transition $\left(\mathrm{R}_{\mathrm{PC}}\right)$ was calculated. It was observed that the solidification rate at which the formation of cellular structures begins is greatly different from the calculated value for $\mathrm{R}_{\mathrm{PC}}$. Within experimental range of solidification rate the beginning of plane-to-cell transition was observed.

The effective distribution coefficient $\mathrm{k}_{\mathrm{e}}$ was calculated for each solidification rate. The $\mathrm{k}_{\mathrm{e}}$ reaches maximum at highest solidification rate, while it has minimum for the estimated planar to-cellular transition rate.

\section{REFERENCES}

1. B. Chalmers, Principles of Solidification, Willey \& Sons, New York, 1964.

2. W. G. Phan, Zone Melting, Willey \& Sons, New York, 1958.

3. A. Valcić, V. Radojević, S. Nikolić, The influence of crystallization rate and the initial solute concentration on the crystallization front shape, J. Soc. Chem. Soc. 60 (1): 33 (1995).

4. L. Kuchar, J. Drapala, Výroba vysoce čistých kovu kristalizačnimi metodami, Hutnicke Listy 7: 498 (1985).

5. A. Valčić, S. Nikolić, B. Radonjić, Occurrences along solid-liquid phase boundary, Proceeding of VII World RTC Sintering, H. Novi, p. 156 (1989).

6. A . Valčić, S. Nikolić, B. Radonjić, Kristalizacija kao metoda prečišćavanja zonalnim topljenjem, Proc. XXXIII ETAN, Novi Sad, (1989).

7. V. Radojević, A. Valčić, S. Nikolić, A.Milutinović-Nikolić, Solidification of binary alloy by vertical Bridgman method, Proc. Material's Congress, Cirencester, 49 (1998).

8. A. Valčić, V. Radojević, S. Nikolić, Metode normalnog očvršćavanja i zonalnog topljenja kao metode prečišćavanja aluminijuma, Metalurgija 4(2):237 (1996). 